\title{
Effect of Coloured Agro-Net Covers on Insect Pest Control and Yield of Tomato (Solanum lycopersicon Mill)
}

\author{
Langàt Jelagat Caroline ${ }^{1}$, Mwanarusi Saidi ${ }^{1} \&$ Arnold Opiyo $^{1}$ \\ ${ }^{1}$ Department of Crops, Horticulture and Soils, Egerton, Kenya \\ Correspondence: Mwanarusi Saidi, Department of Crops, Horticulture and Soils, P.O. Box 536-20115, Egerton, \\ Kenya. E-mail: msaidi@egerton.ac.ke
}

Received: June 28, 2017

doi:10.5539/jas.v9n12p283
Accepted: October 12, $2017 \quad$ Online Published: November 15, 2017

URL: https://doi.org/10.5539/jas.v9n12p283

\begin{abstract}
Tomato (Solanum lycopersicon Mill) is one of the most important vegetable crops consumed throughout the world; and is rich in important vitamins, minerals and antioxidants. Production of the crop in open fields is however constrained by several biotic and abiotic stresses that lead to low tomato yields and quality. This study aimed at determining the effects of coloured agro-net covers on microclimate, pest infestation and yield of tomato cultivar "Rio Grande". The study consisted of two trials conducted using a randomized complete block design (RCBD) with five replications and six treatments. Tomato plants were grown under blue, yellow, grey, white or multi-coloured net covers with a no net cover as the control. Data were collected on microclimate (temperature, soil moisture, relative humidity and photosynthetically active radiation), pest counts and crop yield variables. Net covering modified the tomato crop microclimate with highest temperatures and soil moisture and, relative humidity levels recorded under white $\left(21.03{ }^{\circ} \mathrm{C}\right)$, blue $(30.03 \%)$ and multi-coloured net covers $(76.26 \%)$, respectively compared to the no net control treatment $\left(16.32{ }^{\circ} \mathrm{C}, 14.82 \%\right.$ and $\left.64.90 \%\right)$. Photosynthetically active radiation (PAR) was lowest under the blue agro-net cover $\left(416.09 \mu \mathrm{mol} \mathrm{m}^{-2} \mathrm{~s}^{-1}\right)$ and highest under control treatment $\left(985.00 \mu \mathrm{mol} \mathrm{m} \mathrm{m}^{-2} \mathrm{~s}^{-1}\right.$ ). Tomato plants grown under coloured-colour nets (yellow and blue) had lower population of silverleaf whitefly, thrips and aphids while mite population was lower under neutral-colour net covers (white, grey and multi-coloured). The neutral-colour net covers $(24938.87,19525.16$ and $21541.93 \mathrm{~kg} / \mathrm{ha})$ resulted in higher yields compared to coloured-colour net covers (16804.62 and $14551.05 \mathrm{~kg} / \mathrm{ha})$. Results of the study indicate that use of agro-net covers especially the neutral-colour net cover can improve microclimate, protect tomato against insect pests and can be considered a viable strategy for tomato production by smallholder growers.
\end{abstract}

Keywords: Solanum lycopersicon, protected production, microclimate modification, agro-net cover

\section{Introduction}

Tomato is one of the world's most important vegetable crops consumed and ranks second after potato in the world. Present world production stands at 170,750,767 tonnes produced on 5023810 hectares of land (FAO, 2017). In Africa, total production area of tomato increased from 159,593 ha in 1961 to 1,214,227 ha in 2014 and production increased from 1,968,812 tonnes in 1961 to 19,253,066 tonnes in 2014 (FAO, 2017). In sub-Saharan Africa including Kenya, tomato is still among the most commonly grown and consumed vegetable crop as it greatly contributes to food security, nutritional balance and income for resource poor growers (FAO, 2017). It has high nutritional value with important vitamins, mineral and antioxidants (Velioglu et al., 1998) whose consumption has been shown to reduce the risks of cardiovascular diseases and certain types of cancer (Clinton, 1998). Tomato is consumed fresh or utilized in preparation of wide range of processed products such as tomato juice, soup, paste, puree, ketchup, and sauce (Ray et al., 2011). Despite the potential of tomato in improving the livelihoods of rural population, low yields remain a common scenario. Tomato production is however, constrained by insect pests and diseases, and by abiotic factors (Fufa et al., 2011). Although pesticides are available for control of most insect pests of tomato, they are expensive and unaffordable to small scale farmers who are the majority of tomato growers. In addition, such chemicals are hazardous to humans as well as the environment (Weinberger \& Lumpkin, 2005). Greenhouse tomato production has been advocated for as a way of solving some of these problems. However, its adoption in many of the developing countries has been extremely 
slow, due to high investment costs. As a result, majority of farmers still grow their tomato in the open fields, despite all the challenges (HCDA, 2006).

Simple technologies have been developed in different parts of the world and proved successful in protecting crops against adverse weather conditions and insect pests. Netting technology has been used to protect agricultural crops from environmental hazards thus enhancing plant microclimate for improved crop yield and quality (Shahak et al., 2004). Coloured (photo-selective) shading nets are currently being developed with the aim of improving crop production by taking advantage of their optical properties. Coloured nets modify the spectral composition of the transmitted and reflected sunlight (Shahak et al., 2004) which tend to have differential effects on insect pests and crop performance (Shahak et al., 2008; Shahak, 2008). An understanding of the specific effects of the different colours of agro-net covers on tomato pest infestation and microclimate modification would be critical in ensuring better use of the technology. This study aimed at determining the effects of coloured agro-net covers on microclimate, pest infestation and yield of tomato cultivar "Rio Grande".

\section{Materials and Methods}

\subsection{Experimental Site}

Two trials (Nov. 2013 to Feb. 2014 and May to Sep. 2014) were conducted at the Horticulture Research and Demonstration Field, Egerton University, Njoro, Kenya. The field lies at a latitude of $0^{\circ} 23^{\prime} \mathrm{S}$ longitude $35^{\circ} 35^{\prime} \mathrm{E}$ and an altitude of $2238 \mathrm{~m}$. The area receives a mean annual rainfall of about $1000 \mathrm{~mm}$ with average maximum and minimum temperatures ranging from $19{ }^{\circ} \mathrm{C}$ to $22{ }^{\circ} \mathrm{C}$ and $5{ }^{\circ} \mathrm{C}$ to $8{ }^{\circ} \mathrm{C}$, respectively. The soils are well drained dark reddish clays classified as Mollic andosols (Jaetzold \& Schmidt, 2006).

\subsection{Planting Material, Experimental Design and Treatments}

Seeds of tomato cultivar "Rio Grande" sourced from Kenya Seed Company - Eldoret were sowed in a nursery to obtain transplants used as the planting material in this study. This determinate tomato cultivar was chosen because it has good disease tolerance and is high yielding but sensitive to variations in environmental conditions (HCDA, 2006). The experiment was laid in a randomized complete block design (RCBD) with five replications and six treatments. The treatments were growing tomato under; blue, yellow, grey, white and multi-coloured (predominantly white in colour with blue and yellow stripes) net covers maintained permanently covered except during routine management and a no net cover treatment as the control. Agro-net covers used were of $0.4 \mathrm{~mm}$ pore diameter sourced from A to Z Textile Mills Ltd., Arusha, Tanzania. Each block measured $32.5-\mathrm{m} \times 3-\mathrm{m}$ separated by a $0.5-\mathrm{m}$ path from the adjacent block. Within each block, each individual experimental unit measured $3-\mathrm{m} \times 5-\mathrm{m}$ separated by a $0.5-\mathrm{m}$ path. On covered treatments, seven posts $1.2-\mathrm{m}$ long were installed before planting to provide support for the net covers. Three posts were mounted on each side of the experimental unit at $2.5-\mathrm{m}$ apart along the $5-\mathrm{m}$ bed and one at the middle of the plot to serve as support system for the cover. The posts were grounded to $20-\mathrm{cm}$ depth to ensure that they were firm enough to provide the needed support leaving 1-m of the length of posts above the ground. Agro-nets were then mounted completely covering the plots and pegged at each corner to minimize wind interference. The plots were permanently covered and only opened during routine management and data collection periods.

\subsection{Land Preparation, Planting and Maintenance Practices}

The field was manually prepared using hoes and rakes. Transplanting holes were manually dug using hand hoe and diammonium phosphate fertilizer $\left(18 \% \mathrm{~N}, 46 \% \mathrm{P}_{2} \mathrm{O}_{5}\right)$ incorporated in every planting hole at a rate of $10 \mathrm{~g}$ and thoroughly mixed with soil prior to transplanting. Tomato seedlings at the four true leaf stage were transplanted in four rows at $50-\mathrm{cm}$ spacing within the row and giving a total of 40 tomato plants per experimental unit. Thereafter, standard good agricultural practices including; gapping, top dressing, watering, weeding and disease control were done uniformly in all experimental units on need basis. Calcium Ammonium Nitrate (CAN) was applied in two splits as a top dress at the rate of $300 \mathrm{~kg} \mathrm{ha}^{-1}$ when plants were three weeks old and the second split three weeks later.

\subsection{Data Collection}

Data for all variables studied were measured from 12 plants in the inner rows of each experimental unit.

Microclimate: WatchDog 2000 series Mini Station data loggers (2475; Spectrum Technologies, Inc.) were used to collect microclimate data. The data loggers were mounted on wooden posts $0.5-\mathrm{m}$ high at the centre of each experimental unit and were set to collect data hourly which were averaged weekly. On weekly basis, the data were downloaded into a computer. Microclimate data collected included; air temperature $\left({ }^{\circ} \mathrm{C}\right)$, relative humidity (\%), PAR light $\left(\mu \mathrm{mol} \mathrm{m} \mathrm{m}^{-2} \mathrm{~s}^{-1}\right)$ and soil moisture as volumetric water content (\%) using an external sensor (WaterScout ${ }^{\mathrm{TM}} \mathrm{SM}$ 100; Spectrum Technologies). 
Insect pest counts: Data were collected on the number of adult silverleaf whitefly (Bemisia tabaci), spider mites (Tetranychus urticae) and onion thrips (Frankliniella intonsa) and nymphs of aphid (Aphis gossypii). Hand lens were used to produce magnified images of small insects (mites and thrips). In the case of whitefly, yellow sticky traps from Koppert Biological Systems (K) Ltd., Nairobi, Kenya were also mounted on each plot to trap flying whiteflies and later counted.

Fruit yield: Fruit harvesting was done once every week beginning when the first fruits were at breaker stage and continued for a period of four weeks. At each harvest, tomato fruit from each tagged plant were separately counted and the number of fruits obtained recorded and later used to compute the average number of fruits per plant (no./plant). Thereafter, tomato fruits harvested from each experimental unit were then separately sorted as marketable and unmarketable. Unmarketable fruits included small size fruits $(<30 \mathrm{~mm}$ in diameter), those damaged by insects or diseases and those with physical damage or physiological defects. The data obtained were used to compute marketable and unmarketable fruits per plant. The fruits for each category were then weighed and weight obtained recorded in grams and later used to compute the total fruit weight, marketable and unmarketable fruit weight in kilograms per hectare $\left(\mathrm{kg} \mathrm{ha}^{-1}\right)$.

\subsection{Data Analysis}

Data collected were subjected to Analysis of Variance (ANOVA) using PROC GLM code of SAS (version 9.1; SAS Institute, Cary, NC, USA). Data were analyzed using the statistical RCBD model: $Y_{\mathrm{ijk}}=\mu+\beta_{\mathrm{j}}+\mathrm{T}_{\mathrm{k}}+\varepsilon_{\mathrm{ijkl}}$ where, $Y_{i j k}$ is the tomato yield response, $\mu$ is the overall mean, $\beta_{\mathrm{j}}$ is the effect of the $\mathrm{j}^{\text {th }}$ block $(\mathrm{j}=1,2,3,4,5), \mathrm{T}_{\mathrm{k}}$ is the effect of the $\mathrm{k}^{\text {th }}$ treatment $(1,2,3,4,5)$ and $\varepsilon_{\mathrm{ijkl}}$ is the random error component. Means for significant treatments were separated using Tukey's Honestly Significant Difference (Tukey's HST) test at $\mathrm{P} \leq 0.05$.

\section{Results}

\subsection{Effects of Different Colours of Agro-Net Cover on Tomato Plant Microclimate}

Covering tomato with agro-net covers of different colours influenced microclimate of the immediate crop environment. Air temperature, relative humidity and soil moisture (measured in volumetric water content) were higher while PAR was reduced under agro-net covered plots compared to under the control treatment (Figure 1). Throughout the study, temperatures were highest under the white cover. Mean temperature for this treatment for the two trials was $21.03{ }^{\circ} \mathrm{C}$. Among the other treatments, mean temperatures were $18.75{ }^{\circ} \mathrm{C}, 18.24{ }^{\circ} \mathrm{C}, 17.94{ }^{\circ} \mathrm{C}$, $17.12{ }^{\circ} \mathrm{C}$ under yellow, grey, multi-coloured, and blue net covers, respectively compared with $16.32{ }^{\circ} \mathrm{C}$ for the control treatment (Figure 1A). Averaged over the two trials, relative humidity was lowest under the control treatment at $64.90 \%$ and highest under the multi-coloured cover at $76.26 \%$ (Figure 1B). Among the other treatments, mean relative humidity was recorded as $73.91 \%$ under grey cover followed by $72.46 \%$ under blue cover, then $69.78 \%$ under yellow cover and $67.35 \%$ under white cover.

Averaged over the two trials, soil moisture content was lowest under the control treatment (14.82\%) and highest under blue cover $(30.03 \%$ ) (Figure 1C). Among the other treatments, the highest soil moisture content was obtained under yellow cover $(26.75 \%)$ followed by multi-coloured $(24.23 \%)$ then white cover $(23.14 \%)$ with moisture content being lowest under grey net cover (23.03\%). To the contrary, the use of different colours of agro-net cover reduced PAR (Figure 1D) reaching the crop throughout the study period. The mean PAR received by plants was highest under the control treatment $\left(985.00 \mu \mathrm{mol} \mathrm{m}^{-2} \mathrm{~s}^{-1}\right)$ and lowest under blue cover (416.09 $\mu \mathrm{mol} \mathrm{m} \mathrm{m}^{-2} \mathrm{~s}^{-1}$ ). Among the other treatments, PAR values were $679.48 \mu \mathrm{mol} \mathrm{m}^{-2} \mathrm{~s}^{-1}$ under white cover, 624.64 $\mu \mathrm{mol} \mathrm{m} \mathrm{m}^{-2}$ under multi-coloured cover, $539.17 \mu \mathrm{mol} \mathrm{m} \mathrm{s}^{-2}$ under grey cover and $447.05 \mu \mathrm{mol} \mathrm{m} \mathrm{m}^{-2} \mathrm{~s}^{-1}$ under yellow cover.

\subsection{Effects of Different Colours of Agro-Net Cover on the Population of Tomato Insect Pest}

The number of silverleaf whitefly, aphids, onion thrips, and mites on the tomato crop were significantly reduced following the use of the different coloured agro-net covers (Table 1). During all data collection periods, the lowest population of silverleaf whitefly was observed under the yellow net followed by grey cover, then white then multi-coloured cover while the highest population was obtained under the control treatment with no net cover. Among the net covered treatments, whitefly population was highest under the blue cover in all sampling dates. Silverleaf whitefly data collected from the sticky traps mounted at the centre of each plot showed a trend similar to that of the populations obtained on individual plants with the lowest and highest whitefly population observed under the yellow cover and control, respectively. 
A

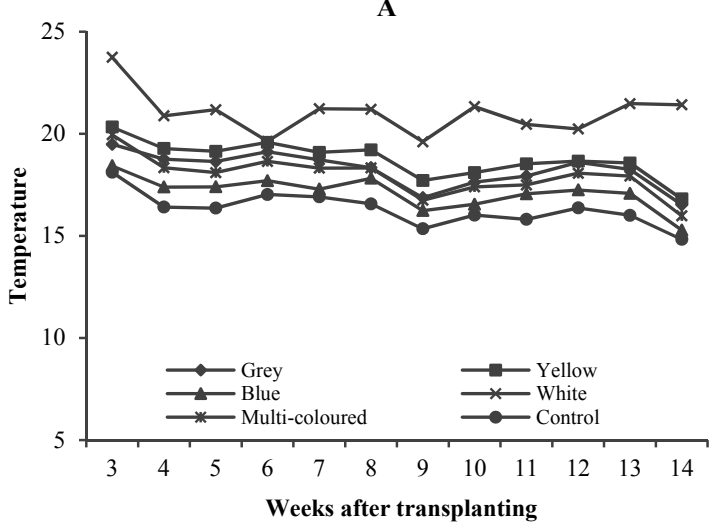

C

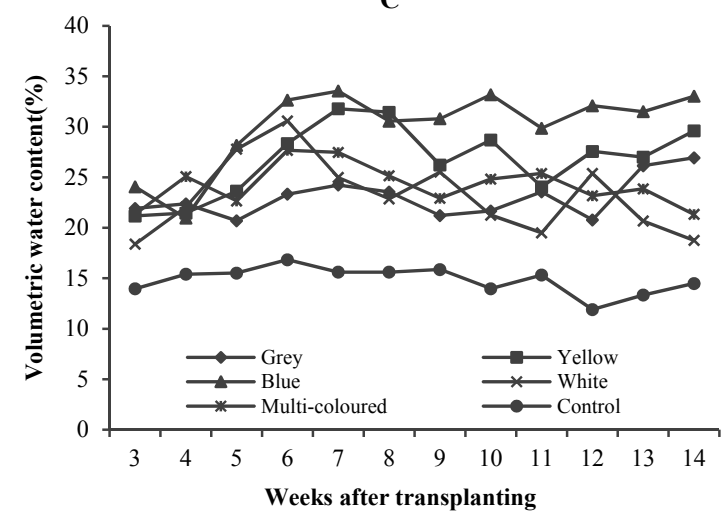

B

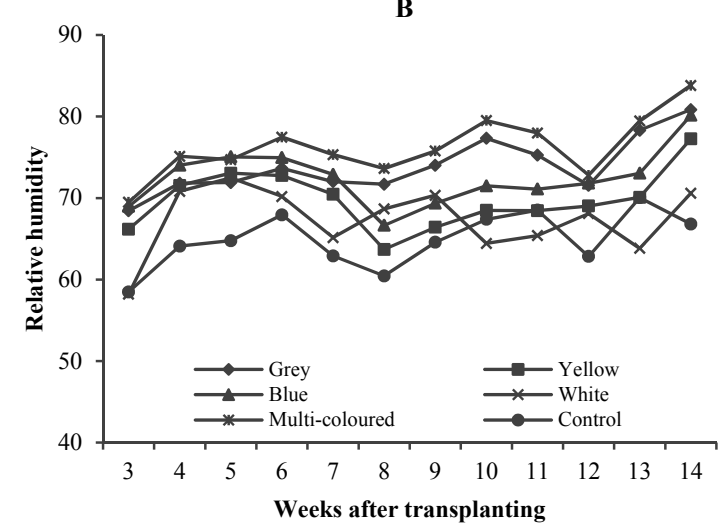

D

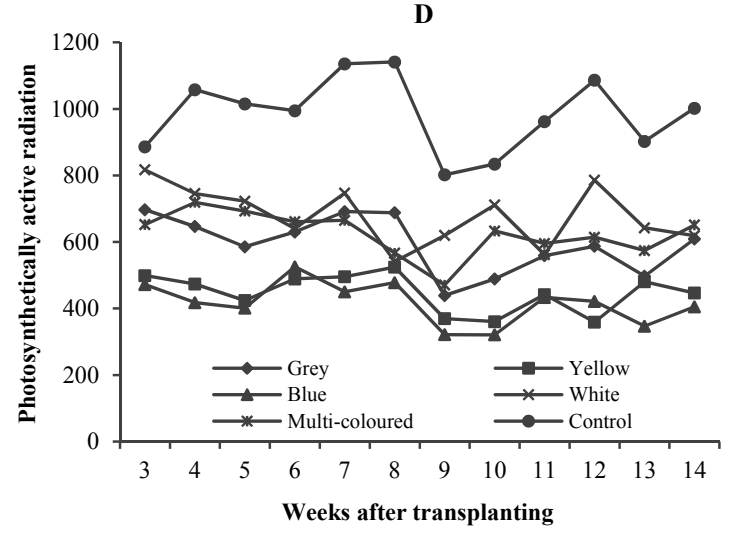

Figure 1. Air Temperature (A), Relative Humidity (B), Soil Moisture (C) and Photosynthetically Active Radiation (D) as influenced by different colours of agro-net cover

Aphid numbers was lowest under the yellow and white net covers with intermediate aphid numbers recorded under the grey, blue and multi-coloured covers in most sampling dates while the highest population was obtained under the control treatment in all sampling dates. Thrips population was on the other hand lowest under the blue net cover in all sampling dates and highest under the control treatment. Among the other treatments, the numbers of thrips recorded on individual plants was lower under the yellow net cover than under multi-coloured, grey and white covers with no statistical differences noted in the mean number of thrips recorded for these treatments in all sampling dates. The lowest mite population was recorded under the grey cover throughout the study period except at 56 DAT when mite population was lowest under the white cover. Among the other treatments, mite numbers tended to be lower under the white cover followed by yellow cover but slightly higher under the multi-coloured cover in most sampling dates. Throughout the study period, mite population on plants was highest under the control treatment. 
Table 1. Effect of different colours of agro-net cover on pest population of tomato plants

\begin{tabular}{|c|c|c|c|c|}
\hline \multirow{2}{*}{ Treatment } & \multicolumn{4}{|c|}{ Days after Transplanting } \\
\hline & 28 & 56 & 70 & 84 \\
\hline \multicolumn{5}{|c|}{ Silverleaf whitefly/plant } \\
\hline Grey & $1.49 \mathrm{~b}^{*}$ & $1.39 \mathrm{bc}$ & $1.38 \mathrm{~cd}$ & $1.38 \mathrm{~b}$ \\
\hline Yellow & $1.21 \mathrm{~b}$ & $1.19 \mathrm{c}$ & $0.94 \mathrm{~d}$ & $0.94 \mathrm{c}$ \\
\hline Blue & $2.00 \mathrm{a}$ & $2.02 \mathrm{a}$ & $1.91 \mathrm{ab}$ & $2.50 \mathrm{a}$ \\
\hline White & $1.62 \mathrm{ab}$ & $1.80 \mathrm{ab}$ & $1.60 \mathrm{bc}$ & $1.41 \mathrm{~b}$ \\
\hline Multi-coloured & $1.70 \mathrm{ab}$ & $1.83 \mathrm{ab}$ & $1.26 \mathrm{~cd}$ & $1.40 \mathrm{~b}$ \\
\hline Control & $2.07 \mathrm{a}$ & $2.18 \mathrm{a}$ & $2.09 \mathrm{a}$ & $2.76 \mathrm{a}$ \\
\hline \multicolumn{5}{|c|}{ Silverleaf whitefly on yellow traps/plot } \\
\hline Grey & $1.95 \mathrm{~b}$ & $2.05 \mathrm{bc}$ & $2.23 \mathrm{bc}$ & $1.71 b c$ \\
\hline Yellow & $1.49 \mathrm{c}$ & $1.73 \mathrm{c}$ & $1.93 \mathrm{c}$ & $1.45 \mathrm{c}$ \\
\hline Blue & $2.27 \mathrm{~b}$ & $2.39 \mathrm{~b}$ & $2.52 \mathrm{~b}$ & $2.05 \mathrm{~b}$ \\
\hline 'White & $2.15 b$ & $2.25 \mathrm{~b}$ & $2.40 \mathrm{~b}$ & $1.88 \mathrm{~b}$ \\
\hline Multi-coloured & $2.06 \mathrm{~b}$ & $2.15 b$ & $2.35 \mathrm{~b}$ & $1.97 \mathrm{~b}$ \\
\hline Control & $2.97 \mathrm{a}$ & $3.05 \mathrm{a}$ & $3.14 \mathrm{a}$ & $2.59 \mathrm{a}$ \\
\hline \multicolumn{5}{|l|}{ Aphids/plant } \\
\hline Grey & $0.64 \mathrm{ab}$ & $1.24 \mathrm{~b}$ & $1.15 \mathrm{~b}$ & $1.31 \mathrm{~b}$ \\
\hline Yellow & $0.40 \mathrm{c}$ & $1.16 \mathrm{~b}$ & $1.26 \mathrm{~b}$ & $1.22 \mathrm{~b}$ \\
\hline Blue & $0.62 \mathrm{ab}$ & $1.28 \mathrm{ab}$ & $1.35 \mathrm{~b}$ & $1.29 b$ \\
\hline White & $0.44 \mathrm{c}$ & $1.11 \mathrm{~b}$ & $1.17 \mathrm{~b}$ & $1.21 \mathrm{~b}$ \\
\hline Multi-coloured & $0.52 \mathrm{bc}$ & $1.22 \mathrm{~b}$ & $1.32 \mathrm{~b}$ & $1.27 \mathrm{~b}$ \\
\hline Control & $0.71 \mathrm{a}$ & $1.46 \mathrm{a}$ & $1.61 \mathrm{a}$ & $1.70 \mathrm{a}$ \\
\hline \multicolumn{5}{|l|}{ Mites/plant } \\
\hline Grey & 0.85 & $0.91 b c$ & $0.67 \mathrm{c}$ & $1.15 \mathrm{~b}$ \\
\hline Yellow & 0.94 & $0.82 \mathrm{bc}$ & $0.76 b c$ & $1.27 \mathrm{ab}$ \\
\hline Blue & 1.21 & $1.07 \mathrm{ab}$ & $1.04 \mathrm{~b}$ & $1.52 \mathrm{ab}$ \\
\hline White & 0.93 & $0.69 \mathrm{c}$ & $0.82 \mathrm{bc}$ & $1.19 \mathrm{~b}$ \\
\hline Multi-coloured & 1.00 & $0.70 \mathrm{c}$ & $0.87 \mathrm{bc}$ & $1.31 \mathrm{ab}$ \\
\hline Control & 1.22 & 1.28 & $1.41 \mathrm{a}$ & $1.62 \mathrm{a}$ \\
\hline \multicolumn{5}{|l|}{ Thrips/plant } \\
\hline Grey & $0.65 \mathrm{ab}$ & $1.00 \mathrm{ab}$ & 0.97 & $0.62 b$ \\
\hline Yellow & $0.47 \mathrm{~b}$ & $0.96 a b$ & 0.79 & $0.63 b$ \\
\hline Blue & $0.41 b$ & $0.67 \mathrm{~b}$ & 0.71 & $0.51 \mathrm{~b}$ \\
\hline White & $0.70 \mathrm{ab}$ & $1.05 \mathrm{a}$ & 0.94 & $0.73 b$ \\
\hline Multi-coloured & $0.65 \mathrm{ab}$ & $1.17 \mathrm{a}$ & 0.93 & $0.89 \mathrm{ab}$ \\
\hline Control & $0.97 \mathrm{a}$ & $1.12 \mathrm{a}$ & 0.98 & $1.32 \mathrm{a}$ \\
\hline
\end{tabular}

Note. * Means followed by the same letter within a column and a variable are not significantly different according to Tukey's honest significant difference (HSDT) test at $\mathrm{P} \leq 0.05$.

\subsection{Effects of Different Colours of Agro-Net Covers on the Yield of Tomato}

Growing tomato under the different coloured net covers significantly influenced tomato fruit yield both in terms of fruit numbers and fruit weight (Table 2). The use of white net cover resulted in the highest fruit number per plant with the lowest fruit number per plant obtained under the blue net cover. Among the other treatments, more fruits were harvested from plants under multi-coloured net cover followed by the control, grey net cover and yellow net cover in descending order. Upon separation of fruits into marketable and unmarketable fruits, the highest number of marketable fruits was also obtained under the white net cover while the lowest number was under the blue net cover. Among the other treatments, the number of marketable fruits obtained was in descending order from multi-coloured, grey, yellow and control treatment. 
Table 2. Effect of different colours of agro-net cover on yield of tomato

\begin{tabular}{|c|c|c|c|c|c|}
\hline \multicolumn{6}{|c|}{ Tomato fruit number/plant } \\
\hline Treatments & Number of fruits & Marketable fruits & $\%$ relative increase & Unmarketable fruits & $\%$ relative decrease \\
\hline Grey & $42.00 \mathrm{bc} *$ & $26.60 \mathrm{bc}$ & 40.74 & $15.40 \mathrm{bc}$ & 39.37 \\
\hline Yellow & $34.80 \mathrm{~cd}$ & $23.00 \mathrm{bc}$ & 21.69 & $11.80 \mathrm{c}$ & 53.54 \\
\hline Blue & $29.00 \mathrm{~d}$ & $17.90 \mathrm{c}$ & -5.29 & $11.10 \mathrm{c}$ & 56.30 \\
\hline White & $53.00 \mathrm{a}$ & $36.80 \mathrm{a}$ & 94.71 & $16.20 \mathrm{bc}$ & 36.22 \\
\hline Multi-coloured & $47.70 \mathrm{ab}$ & $28.70 \mathrm{ab}$ & 62.43 & $19.00 \mathrm{~b}$ & 33.07 \\
\hline Control & $44.30 \mathrm{abc}$ & $18.90 \mathrm{c}$ & & $25.40 \mathrm{a}$ & \\
\hline \multicolumn{6}{|c|}{ Tomato fruit weight $\left(\mathrm{KgHa}^{-1}\right)$} \\
\hline Treatments & Total fruit weight & Marketable fruit weight & $\begin{array}{l}\% \text { relative increase } \\
\text { in marketable weight }\end{array}$ & $\begin{array}{l}\text { Unmarketable fruit } \\
\text { weight }\end{array}$ & $\begin{array}{l}\% \text { relative decrease } \\
\text { in unmarketable weight }\end{array}$ \\
\hline Grey & $19525.16 \mathrm{abc}$ & $12414.34 \mathrm{bc}$ & 41.36 & $7110.82 \mathrm{a}$ & 1.45 \\
\hline Yellow & $16804.62 b c$ & $11650.68 b c$ & 32.67 & $5153.95 \mathrm{ab}$ & 28.57 \\
\hline Blue & $14551.05 b$ & $10966.34 \mathrm{bc}$ & 24.88 & $3584.73 b$ & 50.32 \\
\hline White & $24938.87 \mathrm{a}$ & $17830.68 \mathrm{a}$ & 103.04 & $7108.19 \mathrm{a}$ & 1.49 \\
\hline Multi-coloured & $21541.93 \mathrm{ab}$ & $15131.37 \mathrm{ab}$ & 72.30 & $6320.56 \mathrm{ab}$ & 12.41 \\
\hline Control & $15997.52 b c$ & $8781.84 \mathrm{c}$ & & $7215.68 \mathrm{a}$ & \\
\hline
\end{tabular}

Note. ${ }^{*}$ Means followed by the same letter within a column and a variable are not significantly different according to Tukey's honest significant difference (HSDT) test at $\mathrm{P} \leq 0.05$.

Contrary to marketable fruit numbers, the lowest number of unmarketable fruits per plant was realized under the blue net cover while the highest number was obtained under the control treatment. Among the other treatments, the number of unmarketable fruits obtained was in ascending order from yellow, to grey, to white covers and highest under the multi-coloured cover.

Fruit weight per plant followed a trend similar to that of fruit numbers with the highest and lowest total fruit weight obtained under the white and blue net covers, respectively (Table 2). Among the other treatments, higher total fruit weight was obtained under the multi-coloured net, followed by under the grey net, then yellow net and lowest under the control treatment with no net cover. On the other hand, the highest marketable fruit weight was obtained under the white net and the lowest under the control treatments. Among the other treatments, marketable fruit was higher under the multi-coloured net, followed by the grey net then the yellow net and the lowest under the blue net. Marketable fruit yield was 103.04\% higher under the white net cover, $72.03 \%$ higher under the multi-coloured net, $41.36 \%$ higher under the grey net, $32.67 \%$ under the yellow net and $24.88 \%$ under the blue net compared to control plants. Unmarketable fruit weight recorded a trend almost opposite to that of marketable fruit weight, with the highest unmarketable fruit weight obtained under the control treatment and the lowest under the blue net cover. Among the other treatments, unmarketable fruit weight was highest under the grey net followed by the white net then under the multi-coloured and lowest under the yellow net cover.

\section{Discussion}

Growing tomato under the different coloured agro-net cover proved to be of potential benefit in the production of tomato. Regardless of the colour of agro-net cover, net covers modified the microclimate around the growing tomato plants marked by higher air temperature, soil moisture and relative humidity compared with the control treatment. On the other hand, photosynthetically active radiation was reduced by the use of coloured agro-net covers. The existence of net covers has been shown to alter the exchange of radiation, momentum and mass between the crop and the atmosphere hence modifying plant micro-environment. Netting also offers a partial barrier (Bextine \& Wayandande, 2001) that reduce the mixing of outside air with inside air thus reducing heat loss to the surrounding atmosphere, which leads to temperature build up (Tanny et al., 2003). In the current study, temperatures generally tended to be higher under neutral-colour net covers (white, multi-coloured and grey) than under coloured-colour net covers (blue, and yellow). Similarly, (Tinyane et al., 2013) recorded higher temperatures under neutral-colour net covers compared to coloured-colour net covers while working on tomato cultivars which was attributed to transparent and less densely knitted pattern of the threads under neutral-colour net covers that transmitted high amounts of light. Higher air temperature recorded under neutral-colour net covers (white, multi-coloured and grey) in the current study could also probably have been as a result of higher light transmission in these treatments compared to coloured-colour net covers. 
Relative humidity was also higher under the coloured agro-net covers than in the uncovered plots in the current study. According to Elad et al. (2007), relative humidity is often higher under nets than outside, as a result of water vapour being transpired by the crop and reduced mixing of drier air outside with that of the netted area, even when the temperatures under netting are higher than outside. Reduction in radiation resulting from netting also contributes to increased relative humidity (Stamps, 1994). Besides reducing radiation, nettings also reduce wind speed and wind run which in turn decreases evaporation due to reduced air mixing which result in an increase in relative humidity (Elad et al., 2007). These arguments lend support to the observations made in the current study where a higher relative humidity was observed under agro-net covered plots than in the uncovered plots. Among the agro-net covered plots, relative humidity tended to be higher under coloured-colour net covers than under neutral-colour net covers possibly due to the relatively higher soil moisture, and lower air temperature and light intensities recorded under coloured-colour net covers compared to under neutral-colour net covers.

Similar to relative humidity and temperature, volumetric water content also tended to be higher under agro-net covers than the control plots in the current study. Use of shade netting, regardless of colour reduces solar radiation levels reaching crops underneath resulting to a decrease in evaporation, thus maintaining higher soil moisture content (Elad et al., 2007). Air movement is also restricted under net covers (Nair \& Ngouajio, 2010) which results in reduced wind damage to the crop allowing air beneath the nets to remain humid (Ilic et al., 2012). Iglesias and Alegre (2006) also demonstrated that reduction of transpiration under net covers led to increased moisture retention in the soil due to minimized water uptake by plants. Besides reduced transpiration rates, existence of a net cover may also have reduced soil evaporation rate under netted areas due to restricted air movement, resulting in higher soil water retention. Findings of the current study corroborate those of earlier studies on spinach (Meena et al., 2014), and cabbage under net covers (Muleke et al., 2014). Among the agro-net covers, soil moisture tended to be higher under coloured-colour net covers than under neutral-colour net covers possibly due to the higher relative humidity levels and lower air temperature recorded under coloured-colour net covers than under neutral-colour net covers that may have contributed to reduced evapotranspiration rate and higher soil moisture levels.

Contrary to temperature, soil moisture and relative humidity, photosynthetically active radiation that reached the tomato crop were lowered by the use of the different coloured agro-net covers compared to no net control. Netting is frequently used to offer physical protection against excessive solar radiation (Shahak et al., 2004) and exhibits special optical properties that allow control of light that reaches the plants (Oren-Shamir et al., 2001). Covers have also been shown to block light from entering into the canopy of plants (Arthurs et al., 2013). The reduction in PAR under covers in the current study could therefore be attributed to the light blocking properties of the materials. Both, the direct and diffuse transmission factor of the net determines the light inside the net covered structure (Hemming et al., 2012). Since neutral-colour nets scatter higher amount of light resulting into availability of more diffused radiation capable of reaching a larger volume of the plant, in a more homogenous way (Nissim-Levi et al., 2008). Coloured-colour net covers essentially act as opaque material giving less reflection of all light spectra (Shahak, 2008). A net having a high transmission factor for diffuse light and a high transmission gives more light intensity (Hemming et al., 2012). According to Castellano et al. (2008), neutral-colour net covers have a higher transmissivity values compared to coloured-colour net covers due to higher values of reflectivity. This could explain the higher PAR recorded under the neutral-colour net covers compared to under coloured-colour net covers in the current study.

The population of silverleaf whitefly, aphids, thrips and mites remained lower under different coloured agro-net covers compared to open field production in the current study. Net covers have been reported to be effective physical barrier excluding a wide range of lepidopteron pests from growing plants (Gogo et al., 2014). Besides, nets have properties to filter the UV radiation $(280-400 \mathrm{~nm})$ interfering with the vision of insect pests and hence their ability to see and discern the host plants (Shahak et al., 2004). The elimination of the UV portion of the light spectrum interferes with UV vision of insects and as a consequence, their behaviour related with movement, host location ability and their population parameters (Diaz \& Fereres, 2007) hence lowering their population under agro-net covers. These arguments support the observations made in the current study where a reduced number of pests was observed under agro-net covered plots than in the uncovered plots.

In the current study, pest population variables were differently influenced by the different coloured net covers. A greater reduction in silverleaf whitefly and aphid population was realized when tomato was grown under the yellow net cover. Reduced number of silverleaf whitefly and aphids observed under the yellow net cover can be attributed to the pigments contained under this net cover that attracts whiteflies and aphids. Therefore, crops grown under these nets could potentially be at a lower risk of pest infestation (Antignus \& Ben-Yakir, 2004). According to (Ben-Yakir et al., 2012), the optical property and light reflection of yellow net cover makes 
whiteflies and aphids land and stay arrested on it for an extended period of time without penetrating through the net. These arguments lend support for the reduced number of silverleaf whitefly and aphid population registered under the yellow net cover compared to other different colours of agro-net covers observed in the current study. Blue net cover also contain pigments known to attract thrips (Shahak, 2008). Growing tomato under blue net cover could potentially be at lower risk of thrips infestation. The lower number of thrips recorded under blue net cover compared to other coloured agro-net covers could be attributed to pigments contained in the net that attracted thrips and stayed arrested on it for an extended period of time without penetrating through the net number in the current study.

Higher number and total fruit weight of tomato was obtained under neutral-colour net covers (white, grey and multi-coloured) compared to coloured-colour net covers (yellow and blue). The higher yield under these nets in the current study can be associated to more light scattering that result into availability of more diffused radiation in a more homogenous way causing higher absorption of PAR resulting to more light use efficiency (LUE), photosynthetic rate and dry matter accumulation (Shahak, 2008). According to Lloyd (1995), enhancement of light has been reported to increase radiation absorbed by the crop, stomatal conductance and net carbon dioxide assimilation leading to increased crop productivity under shading. Spectral modification of composition of light by neutral-colour net covers could have also promoted fruit set and fruitlet survival that led to higher yields. Besides, the increase in yields under neutral-colour net covers could be attributed to the higher number of branches registered under this net covers in the current study compared to under the coloured-colour net covers. The higher yield recorded under neutral-colour net covers could also be attributed to higher light intensity recorded under these net covers compared to coloured-colour net covers. This may have increased number of stomata per $\mathrm{mm}^{2}$ and on the other hand increased overall dry matter content (Salas et al., 2015). Less yield in coloured-colour net covers was observed under the current study. The yellow and blue net covers essentially acts as opaque material which gives less reflection of all light spectra, thereby reducing the photosynthetic activity and fruit yield (Shahak, 2008). The higher yield recorded under neutral-colour net covers over coloured-colour net covers can also be explained by greater exposure to red and far red radiation during growth and development. According to (Kasperbauer \& Hamilton, 1984), the relationship of red and far red solar radiation influences the development of chloroplasts to ensure efficient plant survival, which possibly influenced the photosynthetic capacity promoting a higher productivity. The higher fruit yield from neutral-colour net covers resulted mostly from enhanced fruit production rates, namely the number of fruits produced per plant. Opaque materials reflect radiation out of the structure, decreasing temperature but increasing shading. Excess shading induces etiolation of the plants and redistribution of carbohydrates due to competition for light between plants, likely decreasing fruit yield and quality. Coloured-colour net covers reduced yield of tomato. The low yield under these net covers could be attributed to low number of fruits per plant recorded in the current study. Lower yields recorded under coloured-colour net covers can also be attributed to higher relative humidity recorded under these nets that reduced the crop yield. Meena et al. (2014) observed that higher humidity recorded under the net covers due to sufficient rain, reduced crop yield. According to Nissim-Levi et al. (2008), increased scattered light recorded under pearl net (neutral-colour net) led to plants with a larger number of branches. Lower penetration capacity of blue and red range radiation under coloured-colour net covers reduces photosynthetic activity (Ombodi et al., 2015) possibly explaining the lower yields recorded for coloured-colour net covers in the current study. According to Atkinson et al. (2006), lower productivity under coloured-colour net covers is attributable to the redirection of photo-assimilates for leaf area production in order to increase the solar radiation gathering leaving less energy for the formation of fruit.

Growing tomato under net covers also substantially improved marketable yields of the crop. Better marketable yields obtained under net covers could probably have been as a result of the reduced number of pests from injuring fruits in these treatments in the current study. Net covers also protect crops against direct solar radiation thus avoiding damage to the fruit epidermis and promote better solar radiation distribution within the plant canopy improving quality of fruits (Stamp, 2009). In addition, plant leaf area tends to increase under low light conditions following the use of nets that result in better coverage of the fruit reducing heating of the fruit surface (Gent, 2007). Besides, the modified microclimate (increased air temperature and soil moisture) under covered treatments may also have contributed to the improved crop performance and reduced physiological disorders favouring the production of more fruit that met the market standards. Similarly, Nair and Ngouajio (2010) reported higher marketable yields of cucumber under nets compared with control. The increase in marketable yields recorded in neutral-colour net covers compared to coloured-colour net covers could be attributed to higher production of fruit number and total fruit weight in the current study. 
The use of coloured agro-net covers appears to be a promising technology that can be used for improving tomato yields through modification of microclimate and reduction of insect pest population. For a grower to obtain higher yields and better quality, the use of white net cover in tomato production in regions with similar climatic conditions to those of the site of the current study is recommended. In order to further validate the results, additional studies on the subject using different cultivars of tomato, mesh sizes of the net covers and in different agro ecological zones is recommendable. An analysis of the effects of coloured agro-net covers on plant hydric status and water needs; and beneficial insects and insect vector transmitted diseases would also be beneficial to growers.

\section{Acknowledgements}

This is part of Master of Science in Horticulture project by Caroline Langàt. The authors would like to thank Egerton University and the Department of Crops, Horticulture and Soils for providing the experimental equipment and the field site. We wish also to acknowledge $\mathrm{A}$ to $\mathrm{Z}$ textiles in Tanzania for providing the nets used in the study.

\section{References}

Antignus, Y., \& Ben-Yakir, D. (2004). Ultraviolet absorbing barriers, an efficient integrated pest management tool to protect greenhouses from insects and virus diseases. In A. R Horowitz \& I. Ishaaya (Eds.), Insect Pest Management-Field and Protected Crops (pp. 319-335). Springer Publishers, Berlin. https://doi.org/ 10.1007/978-3-662-07913-3_13

Arthurs, S. P., Stamps, R. H., \& Giglia, F. F. (2013). Environmental modification inside photo-selective shade houses. Hortscience, 48(8), 975-979.

Atkinson, C. J., Dodds, P. A. A., Ford, Y. Y., Miere, J. L. E., Taylor, J. M., Blake, P. S., \& Paul, N. (2006). Effects of cultivar, fruit number and reflected PAR on Fragaria $\times$ annanassa productivity and fruit ellagic acid and ascorbic acid concentrations. Annals of Botany, 97(3), 429-441. https://doi.org/10.1093/aob/mcj046

Ben-Yakir, D., Antignus, Y., Offir, Y., \& Shahak, Y. (2012). Colored shading nets impede invasion and decrease the incidences of insect transmitted viral diseases in vegetable crops. Entomologia Experimentalis et Applicata, 144(3), 249-257. https://doi.org/10.1111/j.1570-7458.2012.01293.x

Bextine, B., \& Wayandande, A. (2001). Effect of insect exclusion on the incidence of yellow vine disease and of the associated bacterium in squash. Plant Diseases, 85, 875-878. https://doi.org/10.1094/PDIS.2001.85. 8.875

Castellano, S., Hemming, S., \& Russo, G. (2008). The influence of colour on radiometric performances of agricultural nets. Acta Hort., 801, 227-236. https://doi.org/10.17660/ActaHortic.2008.801.21

Clinton, S. K. (1998). Lycopene: Chemistry, biology and implications for human health and disease. Nutrition Reviews, 56, 35-51. https://doi.org/10.1111/j.1753-4887.1998.tb01691.x

Diaz, B. M., \& Fereres, A. (2007). Ultraviolet-blocking material as a physical barrier to control insect pests and plant pathogens in protected crops. Pest Technology, 1(2), 85-95.

Doukas, D., \& Payne, D. (2007). The use of ultraviolet- blocking films in insect pest management in the UK; Effects on naturally occurring arthropod pest and natural enemy populations in a protected cucumber crop. Annals of Applied Biology, 151, 221-231. https://doi.org/10.1111/j.1744-7348.2007.00169.x

Elad, Y., Messika, Y., Brand, M., David, D. R., \& Sztejnberg, A. (2007). Effect of colored shade nets on pepper powdery mildew (Leveillula taurica). Phytoparasitica, 35, 285-299. https://doi.org/10.1007/BF02981163

FAOSTAT. (2017). Food and agricultural commodities production. Retrieved June 17, 2017, from http://faostat.fao.org

Fufa, F., Hanson, P., Dagnoko, S., \& Dhaliwal, M. (2009). The world vegetable center tomato breeding in Sub-Saharan Africa: Lessons from the past, present work, and future prospects. Acta Hort., 911, 87-98. https://doi.org/10.17660/ActaHortic.2011.911.10

Gent, P. N. M. (2007). Effect of degree and duration of shade on quality of greenhouse tomato. Hortscience, 42(3), 514-520.

Gogo, E. O., Saidi, M., Itulya, F. M., Martin, T., \& Ngouajio, M. (2014). Eco-friendly nets and floating row covers reduce pest infestation and improve tomato (Solanum lycopersicon L.) yield for smallholder farmers in Kenya. Agronomy, 4, 1-12. https://doi.org/10.3390/agronomy4010001 
Gordon, G. G. (2006). The effects of color plastic mulches and row covers on the growth and production of okra and summer squash (Master's Thesis, Auburn University, Alabama).

Grinberger, A., Shomron M., \& Ganelevin, R. (2000). Shading nets testing (pp. 1-4).

HCDA. (2006). Fruits and Vegetables (p. 150). Agricultural Information Resource Centre, Nairobi, Kenya.

HCDA. (2014). Horticulture Validated Report 2014, USAID-KHCP Horticulture Performance 2012-2014.

Helyes, L., Lugasi, A., Pogonyi, Á., \& Pék, Z. (2009). Effect of variety and grafting on lycopene content of tomato (Lycopersicon lycopersicum L. Karsten) fruit. Acta Aliment Hung, 38(1), 27-34. https://doi.org/ 10.1556/AAlim.2008.0013

Hemming, S., Swinkels, G. L. A. M., Castellano, S., Russo, G., \& Scarascia-Mugnozza, G. (2012). Numerical model to estimate the radiometric performance of net covered structures (pp. 1-23). Wageningen, The Netherlands.

Iglesias, I., \& Alegre, S. (2006). The effect of anti-hail nets on fruit protection, radiation, temperature, quality and profitability of 'Mondial gala' apples. Applied Horticulture, 8(2), 91-100.

Ilic, Z., Milenkovic, L., Durovka, M., \& Kapoutas, N. (2012). The effect of color shade nets on the greenhouse climate and pepper yield. Proceedings $46^{\text {th }}$ Croatian and $6^{\text {th }}$ International Symposium on Agriculture. Opatija.Croatia (pp. 529-532).

Jaetzold, R., \& Schmidt, H. (2006). Farm management handbook of Kenya. Natural conditions and farm management information. Ministry of Agriculture Kenya.

Kasperbauer, M. J., \& Hamilton, J. L. (1984). Chloroplast structure and starch grain accumulation in leaves that received different red and far-red levels during development. Plant Physiology, 74, 967-970. https://doi.org/ 10.1104/pp.74.4.967

Lloyd, J., Chinwong, S., Styles, J. M., Batten, D., Priddle, R., Turnbull, C., \& McConchie, C. A. (1995). Measuring and modelling whole tree gas exchange. Australian Journal of Plant Physiology, 22, 987-1000. https://doi.org/10.1071/PP9950987

Meena, R. K., Vashisth, A., Singh, R., Singh, B., \& Manjaih, K. M. (2014). Study on change in microenvironment under different colour shade nets and its impact on yield of spinach (Spinacia oleracea L.). Agrometeorology, 16(1), 104-111.

Muleke, E. M., Saidi, M., Itulya, F. M., Martin, T., \& Ngouajio, M. (2014). Enhancing cabbage (Brassica oleraceae var. capitata) yields and quality through microclimate modification and physiological improvement using agronet covers. Sustainable Agriculture Research, 3(2), 24-34. https://doi.org/10.5539/ sar.v3n2p24

Nair, A., \& Ngouajio, M. (2010). Integrating row covers and soil amendments for organic cucumber production; implications on crop growth, yield and microclimate. HortScience, 45, 566-574.

Nissim-Levi, A., Lilach, F., David, H., Rinat, O., Izhak, F., Sima, K., \& Oren-Shamir, M. (2008). Light scattering shade net increases branching and flowering in ornamental pot plants. Horticultural Science and Biotechnology, 83, 9-14. https://doi.org/10.1080/14620316.2008.11512340

Ombodi, A., Pek, Z., Szuvandzsiev, P., Taskovics, T. Z., Kohazi-Kis, A., Kovacs, A., ... Helyes, L. (2015). Effects of external coloured shade nets on sweet peppers cultivated in walk-in plastic tunnels. Notulae Botanicae Horti Agrobotanici, 43(2), 398-403. https://doi.org/10.15835/nbha.43.2.9863

Oren-Shamir, M., Gussakovsky, E. E., Shpiegel, E., Nissim-Levi, A., Ratner, K., Ovadia, R., ... Shahak, Y. (2001). Coloured shade nets can improve the yield and quality of green decorative branches of Pittosporum variegatum. Horticultural Science and Biotechnology, 76(3), 353-361. https://doi.org/10.1080/14620316. 2001.11511377

Ray, R. C., El Sheikha, A. F., Panda, S. H., \& Montet, D. (2011). Anti-oxidant properties and other functional attributes of tomato: An overview. International Journal of Food and Fermentation Technology, 1(2), 139-148.

Salas, R. A., Gonzaga, Z. C., Wu, D., Luther, G., Gniffke, P. A., \& Palada, M. C. (2015). Effects of physical barrier and insect growth regulator on whitefly control and yield of chilli pepper (Capsicum annuum L.). Food and Nutrition Science, 3(1-2), 13-19. https://doi.org/10.11648/j.jfns.s.2015030102.13 
Shahak, Y. (2008). Photoselective netting for improved performance of horticultural crops. A review of ornamental and vegetable studies carried out in Israel. Acta Horticulturae, 770, 161-168. https://doi.org/ 10.17660/ActaHortic.2008.770.18

Shahak, Y., Gal, E., Offir, Y., \& Ben-Yakir, D. (2008). Photoselective shade netting integrated with greenhouse technologies for improved performance of vegetable and ornamental crops. Acta Horticulturae, 797, 75-80. https://doi.org/10.17660/ActaHortic.2008.772.7

Shahak, Y., Gussakovsky, E. E., Cohen, Y., Lurie, S., Stern, R., Kfir, S., ... Greenblat-Avron, Y. (2004). Colournets: A new approach for light manipulation in fruit trees. Acta Horticulturae, 636, 609-616. https://doi.org/10.17660/ActaHortic.2004.636.76

Stamps, R. H. (1994). Evapotranspiration and nitrogen leaching during leatherleaf fern production in shadehouses. SJRWMD Spec. Publ. SJ94-SP10. St. Johns River Water Management District, Palatka, FL.

Stamps, R. H. (2009). Use of colored shade netting in horticulture. Hort. Science, 44(2), 239-241.

Tanny, J., \& Cohen, S. (2003). The effect of a small shade net on the properties of wind and selected boundary layer parameters above and within a citrus orchard. Biosystems of Engineering, 84(1), 57-67. https://doi.org/ 10.1016/S1537-5110(02)00233-7

Tinyane, P. P., Sivakumar, D., \& Soundy, P. (2013). Influence of photo-selective netting on fruit quality parameters and bioactive compounds in selected tomato cultivars. Scientia Horticulturae, 161, 340-349. https://doi.org/10.1016/j.scienta.2013.06.024

Velioglu, Y. S., Mazza, G., Gao, L., \& Oomah, B. D. (1998). Antioxidant activity and total phenolics in selected fruits, vegetables and grain products. Agriculture Food Chemistry, 46, 4113-4117. https://doi.org/10.1021/ jf9801973

Weinberger, K., \& Lumpkin, T. A. (2005). Horticulture for poverty alleviation-The unfunded revolution (p. 220). Shanhua, Taiwan. https://doi.org/10.2139/ssrn.781784

\section{Copyrights}

Copyright for this article is retained by the author(s), with first publication rights granted to the journal.

This is an open-access article distributed under the terms and conditions of the Creative Commons Attribution license (http://creativecommons.org/licenses/by/4.0/). 